\title{
ANALISIS KEUNTUNGAN MEBEL KAYU KELAPA DI BLPT KAATEN KOTA TOMOHON PROVINSI SULAWESI UTARA
}

\author{
Fanty Falty Pelealu \\ Joachim N. K. Dumais \\ Audrey J. M. Maweikere
}

\begin{abstract}
This study aims to determine the advantages of coconut wood furniture business at the BLPT Kaaten in Tomohon, North Sulawesi Province. This research was conducted for 3 months from February to April 2018. The data carried out in this study were primary data and secondary data. Primary data were obtained from interviews while secondary data were from the Kaaten BLPT in Tomohon City, North Sulawesi province. The results of the study showed that coconut wood furniture products at the Kaaten BLPT were unique in terms of the design and quality of the products produced. Products are designed according to the wishes of consumers and the quality of wood raw materials is processed to produce good quality wood. Total revenue of Rp. 86,900,000, - minus the total costs incurred in the amount of Rp. 43. 612,599, - the profit obtained from coconut wood furniture for the period of January - March 2018 is Rp. 37,287,401, -. The R / C value of this coconut wood furniture is 1.9, the coconut wood furniture business in the BLPT Kaaten is profitable. *jnkd*.
\end{abstract}

Keywords: profit analysis, wood furniture business, technical education training center (BLPT) Kaaten, Tomohon City, North Sulawesi Province

\begin{abstract}
ABSTRAK
Penelitian ini bertujuan untuk mengetahui keuntungan usaha mebel kayu kelapa di BLPT Kaaten Kota Tomohon Provinsi Sulawesi Utara. Penelitian ini dilakukan selama 3 bulan sejak Februari hingga April 2018. Data yang dilakukan dalam penelitian ini adalah data primer dan data sekunder. Data primer diperoleh dari wawancara sedangkan data sekunder dari BLPT Kaaten Kota Tomohon provinsi Sulawesi Utara. Hasil penelitian yang diperoleh menunjukkan Produk mebel kayu kelapa di BLPT Kaaten mempunyai keunikan dilihat dari rancangan dan mutu produk yang dihasilkan. Produk dirancang sesuai dengan keinginan konsumen dan mutu bahan baku kayu diproses untuk menghasilkan kualitas kayu yang baik. Total penerimaan sebesar Rp. 86.900.000,dikurangi total biaya yang dikeluarkan yaitu sebesar Rp. 43. 612,599,- maka keuntungan yang diperoleh mebel kayu kelapa periode bulan Januari - Maret 2018 yaitu sebesar Rp. 37.287,401,-Nilai R/C dari Mebel Kayu kelapa ini adalah 1,9 maka usaha Mebel Kayu kelapa di BLPT Kaaten ini menguntungkan.
\end{abstract}

Kata kunci: analisis keuntungan, usaha mebel kayu, Balai Latihan Pendidikan Teknik (BLPT) Kaaten, Tomohon, Sulawesi Utara 


\section{PENDAHULUAN}

\section{Latar Belakang}

Indonesia merupakan salah satu Negara agraris yang kehidupan perekonomian tidak bisa lepas dari sektor pertanian. Hal ini karena sektor pertanian masih tetap memegang peran penting yakni dapat meningkatkan pendapatan masyarakat. Tanaman kelapa memiliki kegunaan pada semua bagiannya dimana semua bagian dari tanaman kelapa dapat diolah secara sederhana maupun secara teknologi. Batang kelapa biasanya diolah menjadi bahan bagunan dan dapat diolah menjadi mebel. (Soeka et. al, 2008)

Mebel merupakan salah satu produk industri dan juga merupakan salah satu komoditi hasil kerajinan tangan yang mempunyai peran cukup penting dalam memenuhi kebutuhan masyarakat. Industri mebel merupakan salah satu pemberdayaan usaha mikro kecil menengah (UMKM). Industri mebel merupakan salah satu agenda pembangunan Indonesia dalam rangka meningkatkan kesejahteraan rakyat. Pengembangan UMKM diharapkan dapat menyerap kesempatan kerja sekaligus meningkatkan pendapatan pelakunya (Wulandy dalam Fachmi 2014).

Industri mebel juga salah satu komoditi ekspor Indonesia yang cukup penting sebagai penghasil devisa negara sesudah minyak dan gas, sebagai home industri yang memiliki nilai seni yang cukup tinggi, sehingga industri mebel di negara Indonesia mampu memenuhi kebutuhan masyarakat manca negara. Selain peluang ekspor yang semakin terbuka, pasar industri mebel dalam negeri masih cukup besar meskipun belum digali secara maksimal seperti industri mebel. (Nicholson dalam Fachmi 2014).

Usaha menjadi penting untuk dikembangkan karena sumberdaya yang melimpah dan perluh dikelola dengan baik agar dapat menghasilkan nilai ekonomis, pengolahan sumberdaya alam melalui usaha yang dilakukan oleh satu mebel kayu kelapa dikota Tomohon. BLPT Kaaten Tomohon adalah salah satu pabrik pengolahan dan pemanfaatan batang kelapa menjadi berbagai jenis desain model furniture yang bergerak dalam bidang produksi dan pemasaran yaitu souvenier, mebel, perlengkapan gereja dan bagunan. BLPT Kaaten ini berada dibawah Yayasan Sinode GMIM yang sudah berdiri sejak tahun 1992 memiliki banyak peminat baik lokal maupun mancanegara. Bahan yang digunakan dalam perusahaan ini adalah kayu kelapa yang sangat unik dan berbeda dengan jenis kayu yang lainnya. Selain itu kayu kelapa diperoleh dari daerah Minahasa.

BLPT Kaaten yang mengembangkan industri mebel dengan menggunakan bahan baku utama yaitu kayu kelapa. Kayu kelapa yang digunakan untuk membuat mebel yaitu kayu kelapa yang sudah berumur 60 tahun agar mendapatkan kualitas kayu yang sangat baik. Berbagai tantangan yang ditemui dalam hal ini, salah satunya adalah kenaikan harga kayu akibat sulit mendapatkan kayu kelapa. BLPT Kaaten dihadapkan dengan tantangan tersebut tapi tetap bertahan hingga sekarang, sehingga perlu di analisis berapa keuntungan dari mebel kayu kelapa. Pada periode bulan Januari sampai Bulan Maret 2018, BLPT Kaaten memproduksi bebagai jenis mebel kayu kelapa yaitu Meja "Niky", Kursi "Frank", Lemari Kaca, Kursi Mokupa, Tempat Tidor Primo, Bangku Gereja, Sampiran Gereja, Mimbar Kolom, Sampiran Gereja, Lemari Laci, Asbak Bundar, Vas bunga, Kontak persembahan, Jam meja, Salib besar, Bingkai foto 10 R, Tempat palu, Kotak tissue, Kotak telepon, Tiang bendera 1-3 m, Tongkat komando, Tempat koran, Kursi dapur dan Papan nama duduk. BLPT Kaaten memproduksikan beberapa jenis mebel yang diproduksi namun paling banyak diminati oleh masyarakat pada periode bulan Januari sampai Maret 2018 yaitu 3 jenis mebel. Ketiga jenis mebel tersebut yaitu Meja "Niky", Kursi "Frank" dan Lemari Kaca selanjutnya dijadikan acuan untuk menghitung keuntungan mebel kayu kelapa di BLPT Kaaten Kota Tomohon Provinsi Sulawesi Utara.

\section{Rumusan Masalah}

Berdasarkan latar belakang yang telah diuraikan diatas maka yang menjadi rumusan masalah yaitu berapa besar keuntungan mebel kayu kelapa di BLPT Kaaten kota Tomohon Provinsi Sulawesi Utara. 


\section{Tujuan Penelitian}

Tujuan dari penenelitian ini adalah menganalisis keuntungan usaha mebel kayu kelapa di BLPT Kaaten Kota Tomohon Provinsi Sulawesi Utara.

\section{Manfaat Penelitian}

Manfaat dari penelitian ini agar dapat memberikan informasi bagi pihak yang memerlukannya untuk menambah wawasan dan pengetahuan yang luas mengenai mebel kayu kelapa.

\section{METODE PENELITIAN}

\section{Lokasi Dan Waktu Penelitian}

Penelitian ini dilaksanakan pada BLPT Kaaten Kota Tomohon sebagai industri yang menghasilkan mebel berbahan baku kayu kelapa. Penelitian ini dilakukan selama 3 bulan mulai dari bulan Februari- April 2018.

\section{Metode Pengumpulan Data}

Data yang akan dipakai dalam penelitian ini adalah data primer dan data sekunder. Data primer merupakan data mentah yang diambil oleh peneliti (bukan orang lain) diperoleh dilapangan langsung dari sumbernya yang dalam penelitian ini adalah pemilik usaha mebel kayu kelapa di BLPT Kaaten Kota Tomohon. Data ini diperoleh dari wawancara secara langsung.

Teknik wawancara dilakukan melalui tatap muka dan tanya jawab langsung antara pengumpul data dan narasumbel atau sumber data. Sedangkan data sekunder diperoleh dari studi kepustakan berupa literatur, sumber tertulis atau dokumen yang memiliki relevansi dengan penelitian ini.

\section{Konsep Pengukuran Variabel}

Variabel-variabel yang diukur dalam penelitian ini adalah :

1. Produksi yaitu jumlah produksi mebel

2. Harga yaitu harga jual dari produksi mebel

3. Biaya produksi yaitu biaya yang dikeluarkan dalam proses produksi, yang terdiri : a. Biaya tetap (fixed Cost) meliputi :

- Biaya penyusutan alat

- Pajak

- Bagunan

b. Biaya variabel (Variabel Cost) meliputi:

- Biaya bahan baku

- Biaya tenaga kerja

- Biaya bahan baku penolong

- Biaya sarana listrik

- Biaya telepon

- Biaya transportasi

- Penerimaan (Rp).

4. Penerimaan yaitu perkalian antara produksi yang diperoleh dengan harga jual.

5. Keuntungan $(\mathrm{Rp})$ yaitu nilai yang diperoleh dari hasil penjualan dikurangi dengan biaya yang dikeluarkan.

\section{Analisis Data}

Data yang dikumpulkan dalam penelitian ini kemudian dianalisis dengan menggunakan analisis keuntungan yaitu dengan menghitung selisih antara penerimaan dengan biaya yang digunakan. Data yang dikumpulkan akan disajikan dalam bentuk variabel dan dianalisis secara deskriptif. Dan kemudian di lanjutkan dengan rumus Analisis Revenue Cost Ratio (R/C). Untuk mengukur benar keuntungan digunakan rumus sebagai berikut :

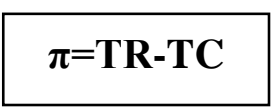

Dimana :

$$
\begin{array}{ll}
\pi & =\text { Profit (Keuntungan) } \\
\text { TR } & =\text { Total Revenue (Total Penerimaan) } \\
\text { TC } & =\text { Total Cost (Total Biaya) }
\end{array}
$$

$$
\mathbf{T R}=\mathbf{Q} \cdot \mathbf{P q}
$$

Dimana :

TR $=$ Total Penerimaan

$\mathrm{Q} \quad=$ Jumlah Produksi yang dijual

$\mathrm{Pq} \quad=$ Harga tiap satuan produk

$$
\mathbf{T C}=\mathbf{F C}+\mathrm{VC}
$$

Dimana :

$\mathrm{TC}($ Total Revenue $) \quad=$ Total Biaya

FC $($ Fixed Cost $)=$ Biaya Tetap

$\mathrm{VC}($ Variabel Cost $) \quad=$ Biaya Variabel 
Kemudian untuk mengetahui apakah mebel kayu kelapa ini menguntungkan atau tidak dapat digunakan dengan rumus:

$$
\begin{gathered}
\mathbf{a}=\mathbf{R} / \mathbf{C} \\
=(\mathbf{P y} . \mathbf{Y}) /(\mathbf{F C}+\mathbf{V C})
\end{gathered}
$$

Apabila:

$\mathrm{R} / \mathrm{C}=1$, Berarti mebel kayu kelapa tidak untung atau tidak rugi

$\mathrm{R} / \mathrm{C}<1$, Berarti mebel kayu kelapa rugi

$\mathrm{R} / \mathrm{C}>1$, Berarti mebel kayu kelapa untung

Dimana :

$$
\begin{aligned}
& \mathrm{a}=\text { Revenue Cost Ratio } \\
& \mathrm{R}=\text { Revenue/Penerimaan } \\
& \mathrm{C}=\text { Cost/Biaya } \\
& \mathrm{Py}=\text { Output Price/Harga Produksi } \\
& \mathrm{Y}=\text { Output/Jumlah Produksi } \\
& \mathrm{FC}=\text { Fixed Cost/Biaya Tetap }
\end{aligned}
$$

\section{HASIL DAN PEMBAHASAN}

\section{Profil Perusahaan}

BLPT Kaaten berdiri pada tahun 1987 yang merupakan salah satu mebel di Sulawesi Utara yang terletak dikota Tomohon. Pada awalnya usaha ini merupakan usaha uji coba yang diberikan nama BKLK. Kemudian usaha ini mengalami perkembangan seiring berjalannya waktu berganti nama menjadi BLPT Kaaten Tomohon pada tanggal 5 Februari 1992. Untuk menyakinkan pembeli bahwa produk yang dihasilkan memiliki kualitas yang baik, aman tahan lama dan menarik, maka BLPT Kaaten menggunakan bahan baku kayu kelapa yang berkualitas juga.

Perabot pohon kelapa banyak diminati dikarenakan serat yang ada dalam pohon kelapa sangat unik dan sangat berbeda dengan kayu kayu jenis lain. Banyak pabrik yang menghasilkan berbagai jenis dan model furniture seperti yang dihasilkan oleh BLPT Kaaten, untuk itu demi menjaga eksistensi BLPT Kaaten dituntut untuk terus meningkatkan kualitas sehingga dapat menghasilkan produk yang berkualitas tinggi dan dapat memenuhi kebutuhan pelanggan.

Jenis yang diproduksikan oleh BLPT Kaaten sangat beragam baik dari bentuk, ukuran dan kualitas. Selain itu juga BLPT Kaaten memproduksikan jenis souvenir dan bahan bagunan yang sangat beragam. BLPT Kaaten juga sudah memiliki pelanggan dari dalam maupun luar negeri yang memesan berbagai jenis mebel dan souvenir. Negara yang pernah diekspor produk dari BLPT Kaaten Tomohon adalah Jerman, Amerika, Belanda, Australia dan Jepang.

BLPT Kaaten Tomohon mempunyai 39 karyawan terdiri dari 8 pekerja perempuan dan 31 pekerja laki-laki, dengan hari kerja senin sampai jumat dan jam kerja senin sampai kamis (08:0004:30) dan pada hari jumat (08:00-03:30). BLPT Kaaten menyediakan tenaga Pendidikan dan pelatihan kepada mahasiswa untuk belajar agar terampil dalam membuat mebel. Selanjutnya jika mahasiswa sudah terampil dalam membuat mebel dapat dipertimbangkan untuk terus bekerja di BLPT Kaaten. Pendidikan dan pelatihan tersebut dilakukan secara gratis.

BLPT kaaten saat ini banyak memproduksi produk yang sesuai permintaan dari pembeli yang diantaranya adalah Meja "Niky", Kursi "Frank" dan Lemari kaca. Dari proses pembuatan sampai pada akhir ini menggunakan mesin yang menghasilkan sesuai dengan produk yang diinginkan dengan karyawan yang sudah ditempatkan pada bagian-bagian yang ditentukan. Produk mebel kayu kelapa di BLPT Kaaten mempunyai keunikan dilihat dari rancangan dan mutu produk yang dihasilkan. Produk dirancang sesuai dengan keinginan konsumen dan mutu bahan baku kayu diproses untuk menghasilkan kualitas kayu yang baik.

\section{Struktur Organisasi}

Berdasarkan hasil observasi di lapangan BLPT Kaaten memiliki struktur organisasi secara tertulis. Gambaran umum mengenai struktrur Organisasi BLPT Kaaten dapat dilihat pada gambar 1 berikut ini:

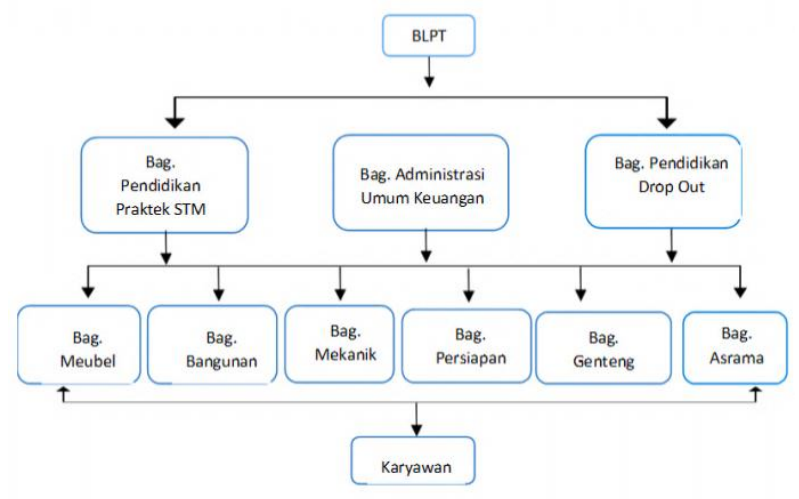

Gambar 1. Struktur Organisasi BLPT Kaaten, Tomohon (2018) 
a. Bagian pendidikan Praktek STM adalah sekolah non formal yang disediakan BLPT untuk siswa-siswa sekolah kejuruan yang akan melakukan praktek dan magang. Bagian pendidikan praktek STM meliputi 1 orang bagian pendidikan dan 1 orang bagian barang kecil/ souvenir.

b. Bagian Administrasi umum dan keuangan terdiri dari 1 orang kepala, 1 orang bagian Produksi, 1 orang bagian Marketing, 1 orang bagian Personalia, 1 orang bagian Operasional, dan 1 orang bagian Adm keuangan yang memiliki tugas berdasarkan jabatan masing-masing.

c. Bagian pendidikan Drop Out Kursus meliputi bagian asrama. Dimana bagian drop out kursus adalah sekolah luar biasa untuk anakanak penyandang cacat.

d. Bagian meubel bertugas untuk membuat produk meubel yang dipesan.

e. Bagian Bangunan bertugas untuk membuat bahan bangunan yang dipesan.

f. Bagian mekanik bertugas untuk memperbaiki mesin mesin yang rusak di BLPT itu sendiri.

g. Bagian persiapan bertugas untuk menyediakan kayu kelapa yang dibentuk sesuai ukuran yang ada.

h. Bagian genteng bertugas untuk membuat genteng bangunan yang dibutuhkan.

i. Bagian asrama bertugas menyediakan asrama untuk siswa yang sedang belajar atau melaksanakan magang di BLPT.

j. Karyawan bertugas untuk melaksanakan seluruh pekerjaan yang telah ditetapkan di masing masing bagian.

\section{Proses Produksi}

Gambar 1 menunjukkan bahwa proses produksi mebel kayu kelapa terdiri dari 4 tahap yaitu :

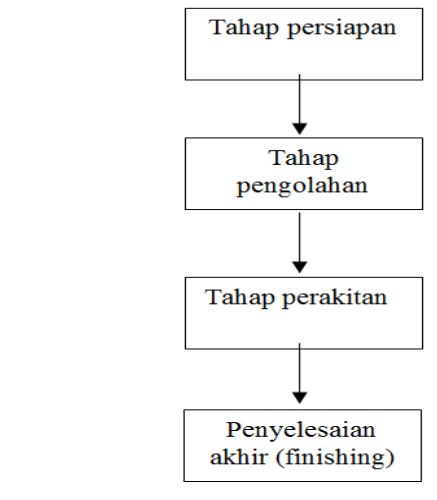

Gambar 1. Proses produksi Mebel kayu kelapa a. Tahap Persiapan

Didalam proses persiapan ini dilakukan pengeringan kayu kelapa, pemotongan kayu kelapa dan penempelan kayu kelapa sesuai dengan desain produk yang sesuai. Di bagian persiapan ini digunakan beberapa mesin untuk melakukan prosesnya yaitu: oven, mesin potong, mesin perata, mesin iris dan mesin penebal. di perusahaan terdapat tiga bilik gudang dimana gudang berfungsi sebagai oven untuk mengurangi kadar air pada bahan baku batang kelapa untuk mendapatkan kepadatan kayu yang ditentukan,bahan baku masuk kedalam gudang untuk dioven yaitu selama 21 hari/ 3minggu setelah itu siap untuk diproduksi.

b. Tahap Pengolahan

Pada tahap pengolahan bahan baku yang siap diproduksikan dipilih warna dan ketebalan yang sama dipotong kayu kelapa dirapikan dan dilubangi sesuai dengan kontruksi sebelum masuk pada tahap perakitan. Di bagian mesin/ pengolahan ini digunakan beberapa mesin untuk melakukan prosesnya yaitu: mesin potong, mesin bor horizontal dan vertikal, mesin iris, mesin pen, mesin frais, mesin bubut, mesin amplas besar dan mesin amplas kecil.

c. Tahap Perakitan

Pada tahap perakitan dimana kayu kelapa yang sudah dipotong dan dibor sesuai dengan pola dan akan dirakit atau disesuaikan dengan model yang diinginkan oleh konsumen. Bagian perakitan digunakan 2 jenis mesin yaitu mesin bor dan mesin Router.

d. Penyelesaian Akhir (Finishing)

Pada bagian ini semua kayu kelapa yang telah dirakit akan diamplas atau dihaluskan pada semua permukaan kayu kelapa yang telah disatukan akan difernis untuk memperindah warna kayu kelapa. Untuk bagian akhir ini digunakan mesin kompressor untuk proses penyelesaiannya.

\section{Penggunaan Bahan Baku}

\section{Bahan Baku Utama}

Produk yang dihasilkan dari suatu perusahaan akan tercipta karena adanya persedian bahan baku. Bahan baku merupakan faktor yang cukup penting terhadap kualitas akhir barang yang diproduksi. Oleh karena itu kualitas bahan baku merupakan pertimbangan utama dalam penyedian dan pembelian bahan baku. 


\begin{tabular}{|c|c|c|c|}
\hline No & Jenis Produk & Jumlah set & Jumlah Unit \\
\hline 1 & Meja “Niky" & 2 & \\
\hline 2 & Kursi "Frank" & & 18 \\
\hline 3 & Lemari kaca & & 3 \\
\hline
\end{tabular}

Tabel 1 menunjukkan bahwa, mebel yang banyak diminati oleh konsumen pada bulan januari sampai maret 2018 adalah kursi "Frank" sebanyak 18 unit, Lemari kaca sebanyak 3 dan Meja "Niky" sebanyak 3 set.

\section{Bahan Baku Penolong}

a. Tahap Persiapan

Kayu kelapa dikeringkan agar supaya dapat mengurangi kadar air dan memiliki ketebalan kayu yang baik agar dapat kualitas kayu yang diinginkan. Bahan baku yang masuk ke dalam oven yaitu selama 21 hari/3minggu setelah itu siap diproduksikan.

b. Tahap Pengolahan

Pada tahap ini kayu kelapa dikeringkan selama 21 hari, kayu kelapa di potong dan dibor sesuai dengan ukuran sesuai dengan

c. Tahap Perakitan

Setelah kayu kelapa telah dirakit sesuai dengan permintaan konsumen kemudian disatukan dengan bahan baku yaitu sebagai berikut:

Tabel 2. Penggunaan Bahan Baku Perakitan

\begin{tabular}{clr}
\hline No & Jenis Bahan & Jumlah \\
\hline 1 & Sekrup & 236 buah \\
2 & Lem & $7,5 \mathrm{~kg}$ \\
3 & Kaca & $3 \mathrm{~mm}$ \\
4 & Kunci & 1 buah \\
5 & Engsel & 4 buah \\
6 & Knock down & 8 buah \\
\hline \multicolumn{2}{l}{ Sumber: Diolah dari Data Primer 2018 }
\end{tabular}

Tabel 2 menunjukkan bahwa jumlah pemakaian bahan lem, sekrup, kaca, kunci, engsel dan knock down bulan januari sampai maret 2018, untuk lem sebanyak 7,65 kg, sekrup yaitu 236 buah, kaca ukuran $60 \times 25$ yaitu 3 mili, kunci yaitu 1 buah, engsel yaitu 4 buah dan knock down yaitu 8 buah.

d. Tahap Penyelesaian Akhir (Finishing)

Tahap Akhir (Finishing) yaitu meliputi proses pengamplasan dan pengecetan. Proses pengamplasan menggunakan kertas amplas yang diletakkan dimesin agar kayu kelapa lebih halus dan untuk memperindah kayu kelapa.pada proses pengecetan digunakan bahan sebagai berikut:

\begin{tabular}{cll}
\multicolumn{2}{c}{ Tabel 3. Penggunaan Bahan Pada Tahap Akhir (Finishing) } \\
\hline No & Jenis Bahan & Jumlah \\
\hline 1 & Cat & $18,175 \mathrm{~kg}$ \\
2 & Wood filler & $3,95 \mathrm{ltr}$ \\
3 & Melamin cending & $8,5 \mathrm{ltr}$ \\
4 & Clear close & $7,25 \mathrm{ltr}$ \\
5 & Thiner & $11,625 \mathrm{ltr}$ \\
6 & Kuas & $46 \mathrm{buah}$ \\
7 & Amplas 120 & $51 \mathrm{lmbr}$ \\
\hline Sumber : & Diolah dari Data Primer, 2018
\end{tabular}

Tabel 3 menunjukkan bahwa, penggunaan bahan baku penolong selama bulan januari sampai maret 2018. Penggunaan cat sebanyak $45 \mathrm{~kg}$, wood filler sebanyak 32 liter, melamin cending sebanyak 6,75 liter, clear close sebanyak 8,05 liter, thiner sebanyak 15,05 liter, kuas sebanyak 32 buah dan amplas 120 sebanyak 13,3 lembar. Bahan tersebut dilarutkan dalam satu wadah kemudian di gunakan sesuai dengan kebutuhan.

\section{Tenaga kerja}

Tenaga kerja merupakan faktor yang penting bagi suatu perusahaan, karena berhasil tidaknya pencapaian tujuan perusahaan dipengaruhi oleh tenaga kerja yang tersedia, dan bekerja sesuai dengan apa yang menjadi tugasnya. Pada usaha mebel kayu kelapa terdapat 24 orang tenaga kerja yang membuat 3 jenis mebel tersebut dan digaji sebesar Rp. 180.000,- per hari. Tenaga kerja dengan sistem upah harian, dengan waktu kerja 8 jam/hari. Jenis kegiatan pekerjaan pada perusahaan ini terbagi 4 tahap yaitu tahap persiapan, tahap mesin, tahap perakitan dan tahap akhir (finishing).

\section{Biaya Produksi}

1. Penyusutan Alat

Tabel 4 menunjukkan bahwa nilai penyusutan mesin dan alat yang terbesar yaitu mesin bor horizontal dan vertikal presentase sebesar $28,14 \%$ kemudian diikuti dengan mesin potong dengan presentase $14,14 \%$ dari total nilai penyusutan mesin dan alat.

Tabel 4. Jenis dan Nilai Penyusutan Mesin dan Alat bulan Januari sampai Maret 2018

\begin{tabular}{|c|c|c|c|}
\hline No & Jenis Barang & Jumlah & Nilai Penyusutan (Rp) \\
\hline 1 & Mesin Potong & 1 & $86.800,00$ \\
\hline 2 & Mesin Perata & 1 & $4.600,00$ \\
\hline 3 & Mesin Iris & 1 & $70.900,00$ \\
\hline 4 & Mesin Penebal & 1 & $32.875,00$ \\
\hline 5 & $\begin{array}{l}\text { Mesin Bor Horizontal \& } \\
\text { Vertikal Besar }\end{array}$ & 1 & $172.700,00$ \\
\hline 6 & Mesin Penebal & 1 & $70.250,00$ \\
\hline 7 & Mesin Frais & 1 & $54.625,00$ \\
\hline 8 & Mesin Bubut & 1 & $10.800,00$ \\
\hline 9 & Mesin Amplas Besar & 1 & $3.875,00$ \\
\hline 10 & Mesin Amplas Kecil & 1 & $1.750,00$ \\
\hline 11 & $\begin{array}{l}\text { Mesin Bor Horizontal \& } \\
\text { Vertikal Kecil }\end{array}$ & 1 & $9.250,00$ \\
\hline 12 & Mesin Routter & 1 & $10.335,00$ \\
\hline 13 & Mesin Kompressor & 1 & $85.000,00$ \\
\hline & & TOTAL & $613.760,00$ \\
\hline
\end{tabular}


Sumber : diolah dari Data Primer, 2018

\section{Biaya Variabel}

Biaya variabel adalah biaya yang digunakan pada kegiatan produksi. Biaya variabel terdiri dari biaya bahan baku, biaya bahan penolong, biaya tenaga kerja, listrik, telepon dan transportasi.

Tabel 5 menunjukkan bahwa biaya bahan baku dan biaya bahan penolong yang terbesar yaitu biaya bahan baku dengan presentase sebesar 74,96\% kemudian diikuti dengan biaya bahan penolong cat dengan presentase $11,60 \%$ dari total biaya bahan baku dan biaya bahan penolong.

\begin{tabular}{cllrr} 
Tabel 5. & \multicolumn{3}{c}{ Biaya Dan Penggunaan Bahan Baku Utama Dan } \\
\multicolumn{1}{c}{ Bahan Penolong Per Set Pada Mebel Meja "Niky" } \\
\hline No & Jenis Bahan & Jumlah & Harga Satuan (Rp) & Jumlah (Rp) \\
\hline 1 & Kayu Kelapa & 0,141 & 8.500 .000 & 1.198 .500 \\
2 & Lem & 1,05 & 25.000 & 26.250 \\
3 & Sekrup & 16 & 500 & 8.000 \\
4 & Cat & 5,3 & 35.000 & 185.500 \\
5 & Wood filler & 0,25 & 40.000 & 10.000 \\
6 & Thiner & 2,025 & 25.000 & 50.625 \\
7 & Kuas & 2 & 2.500 & 5.000 \\
8 & melamin & 0,75 & 55.000 & 41.250 \\
& cending & & & \\
9 & clear close & 0,25 & 55.000 & 13.750 \\
10 & Amplas & 3 & 20.000 & 60.000 \\
\hline \multicolumn{4}{r}{} & \multicolumn{4}{c}{ Total } & 1.598 .875 \\
\hline
\end{tabular}

Tabel 6 menunjukkan bahwa biaya bahan baku dan biaya bahan penolong yang terbesar yaitu biaya bahan baku dengan presentase sebesar 73,73 \% kemudian diikuti dengan biaya bahan penolong amplas dengan presentase $7,89 \%$ dari total biaya bahan baku dan biaya bahan penolong.

Tabel 6. Biaya Dan Penggunaan Bahan Baku Utama Dan Bahan Penolong Per Unit Pada Kursi "Frank"

\begin{tabular}{cllrr}
\hline No & Jenis Bahan & Jumlah & Harga Satuan (Rp) & Jumlah (Rp) \\
\hline 1 & Kayu Kelapa & 0,044 & 8.500 .000 & 374.000 \\
2 & Lem & 0,25 & 25.000 & 6.250 \\
3 & Sekrup & 8 & 500 & 4.000 \\
4 & Knock Down & 8 & 3.000 & 24.000 \\
5 & Cat & 0,25 & 35.000 & 8.750 \\
6 & Wood Filler & 0,15 & 40.000 & 6.000 \\
7 & Thiner & 0,25 & 25.000 & 6.250 \\
8 & Kuas & 2 & 2.500 & 5.000 \\
9 & Melamin Cending & 0,25 & 55.000 & 13.750 \\
10 & Clear Close & 0,35 & 55.000 & 19.250 \\
11 & Amplas & 2 & 20.000 & 40.000 \\
\hline & & TOTAL & 507.250 \\
\hline
\end{tabular}

Tabel 7 menunjukkan bahwa biaya bahan baku dan biaya bahan penolong yang terbesar yaitu biaya bahan baku dengan presentase sebesar $58,95 \%$ kemudian diikuti dengan biaya bahan penolong Kaca dengan presentase 18,36 \% dari total biaya bahan baku dan biaya bahan penolong.

Tabel 7. Biaya Dan Penggunaan Bahan Baku Utama Dan Bahan

\begin{tabular}{|c|c|c|c|c|}
\hline No & Jenis Bahan & Jumlah & Harga Satuan (Rp) & Jumlah (Rp) \\
\hline 1 & Kayu Kelapa & 0,068 & 8.500 .000 & 578.000 \\
\hline 2 & Lem & 0,3 & 25.000 & 7.500 \\
\hline 3 & Sekrup & 20 & 500 & 10.000 \\
\hline 4 & Engsel & 4 & 3000 & 12.000 \\
\hline 5 & Kunci & 1 & 7000 & 7.000 \\
\hline 6 & Kaca & 2 & 90.000 & 180.000 \\
\hline 7 & Cat & 1,025 & 35.000 & 35.875 \\
\hline 8 & Kuas & 2 & 2.500 & 5.000 \\
\hline 9 & Amplas & 3 & 20.000 & 60.000 \\
\hline 10 & Thiner & 1,025 & 25.000 & 25.625 \\
\hline 11 & $\begin{array}{l}\text { Wood Filler } \\
\text { Melamin }\end{array}$ & 0,25 & 40.000 & 10.000 \\
\hline 12 & Cending & 0,75 & 55.000 & 41.250 \\
\hline \multirow[t]{2}{*}{13} & Clear Close & 0,15 & 55.000 & 8.250 \\
\hline & & & TOTAL & 980.500 \\
\hline
\end{tabular}

Tabel 8 menunjukkan bahwa biaya variabel yang terbesar yaitu tenaga kerja dengan presentase sebesar 54,92 \% dan kemudian diikuti dengan biaya bahan baku sebesar $25,35 \%$ dari total biaya variabel.

Tabel 8. Total Biaya Periode Bulan Januari Sampai Maret 2018 di BLPT Kaaten kota Tomohon Provinsi Sulawesi Utara

\begin{tabular}{llr}
\hline No & Jenis Biaya & Jumlah $(\mathbf{R p})$ \\
\hline 1 & Biaya Bahan Baku & 10.863 .000 \\
2 & Biaya Bahan Penolong & 3.445 .000 \\
3 & Biaya Tenaga Kerja & 23.040 .000 \\
4 & Biaya Listrik & 3.630 .000 \\
5 & Biaya Telepon & 520.000 \\
6 & Transportasi & 450.000 \\
7 & Pajak & $551.680,00$ \\
8 & Bagunan & $499.159,00$ \\
9 & Penyusutan alat & $613.760,00$ \\
\hline
\end{tabular}

\section{Penerimaan}

Merupakan perkalian antara produksi yang diperoleh dengan harga jual produk. Dibawah ini adalah tabel penerimaan dan jenis produk mebel kayu kelapa di BLPT kaaten bulan Januari sampai Maret 2018.

Tabel 9 menunjukkan bahwa besar penerimaan pada industri kerajinan mebel kayu kelapa di BLPT kaaten kota Tomohon periode bulan Januari - Maret 2018 yaitu sebesar Rp. 86.900 .000 .

Tabel 9. Penerimaan Dan Jenis Mebel Bulan Januari Sampai Maret 2018

\begin{tabular}{|c|c|c|c|c|}
\hline No & Jenis Barang & Jumlah & $\begin{array}{r}\text { Harga per set atau } \\
\text { per unit (Rp) }\end{array}$ & $\overline{P e n e r i m a a n}(\mathbf{R}$ \\
\hline 1 & Kursi "Frank" & 18 & 2.750 .000 & 49.500 .000 \\
\hline 2 & Meja "Niky" & 2 & 11.500 .000 & 23.000 .000 \\
\hline 3 & Lemari Kaca & 3 & 4.800 .000 & 14.400 .000 \\
\hline & Total & & 19.050 .000 & 86.900 .000 \\
\hline
\end{tabular}

\section{Keuntungan}

Mebel kayu kelapa di BLPT Kaaten dalam proses produksi pada bulan Januari- 
Maret 2018 dengan berbagai macam jenis mebel memiliki selisih hasil penjualan dengan biaya yang disebut keuntungan. Hasil penjualan diperoleh dari perkalian antara harga jual produk dengan jumlah produksi mebel. Sedangkan biaya dihitung dari biaya-biaya yang dikeluarkan dalam proses produksi mebel menyangkut biaya tetap dan biaya variabel. Untuk mengetahui berapa besar keuntungan yang diperoleh dalam meproduksi mebel kayu kelapa sesuai tujuan penelitian ini, maka akan dilakukan analisis keuntungan yaitu pengurangan antara hasil penjualan dengan semua biaya yang dikeluarkan mulai dari produksi sampai produk tersebut terjual atau berada ditangan konsumen.

Analisis Keuntungan Mebel kayu kelapa di BLPT kaaten Kota Tomohon bulan Januari - Maret 2018 yaitu sebagai berikut :

$\begin{array}{ll}\text { Penerimaan } & : 86.900 .000 \\ \text { Total Biaya } & : 43.612,599 \\ \text { Keuntungan } & : 37.287,401\end{array}$

Jadi keuntungan yang diperoleh perusahaan mebel kayu kelapa di BLPT kaaten periode bulan Januari - Maret 2018 yaitu sebesar Rp. 37.287,401-‘.

\section{Revenue Cost Ratio}

Tingkat keuntungan ekonomi dapat diketahui dengan menggunakan Analisis Revenue Cost Ratio ( $R / C$ ratio) adalah perbandingan antara penerimaan dan biaya, ratio yang menjadi parameternya adalah nilai $\mathrm{R} / \mathrm{C}=1$ berarti usaha tidak untung dan tidak rugi, nilai $\mathrm{R} / \mathrm{C}<1$ berarti usaha rugi, nilai $\mathrm{R} / \mathrm{C}>1$ berarti usaha untung. Nilai R/C Usaha Mebel Kayu Kelapa di BLPT Kaaten dapat dilihat bahwa nilai rata-rata $\mathrm{R} / \mathrm{C}$ dari produksi Mebel Kayu Kelapa ini menunjukan angka $>1$. Nilai R/C dari Mebel Kayu kelapa ini adalah 1.9 maka usaha Mebel Kayu kelapa di BLPT Kaaten ini menguntungkan.

\section{KESIMPULAN DAN SARAN}

\section{Kesimpulan}

Produk mebel kayu kelapa di BLPT Kaaten mempunyai keunikan dilihat dari rancangan dan mutu produk yang dihasilkan. Produk dirancang sesuai dengan keinginan konsumen dan mutu bahan baku kayu diproses untuk menghasilkan kualitas kayu yang baik. Total penerimaan sebesar Rp. 86.900.000,- dikurangi total biaya yang dikeluarkan yaitu sebesar Rp. 43. 612,599,- maka keuntungan yang diperoleh mebel kayu kelapa periode bulan Januari - Maret 2018 yaitu sebesar Rp. 37.287,401,-. Nilai R/C dari Mebel Kayu kelapa ini adalah 1,9 maka usaha Mebel Kayu kelapa di BLPT Kaaten ini menguntungkan. Mebel kayu kelapa tergolong industri yang dapat diandalkan dengan melihat besar keuntungan yang diperoleh, selain itu produk yang dihasilkan memiliki kualitas yang baik karena kayu kelapa yang digunakan yaitu kayu kelapa yang sudah berumur 60 tahun dikarenakan serat yang ada dalam pohon kelapa sangat unik dan berbeda dengan jenis kayu lainnya.

\section{Saran}

Berdasarkan hasil penelitian sesuai dengan hasil analisis yang dilakukan maka usaha ini terus dikembangkan. Dari hasil analisis menunjukkan bahwa setiap produk mebel kayu kelapa memberikan keuntungan disetiap produk, oleh sebab itu usaha mebel kayu kelapa dapat lebih diproduksikan dalam jumlah yang besar.

\section{DAFTAR PUSTAKA}

Anonim. 2009. Pemanfaatan Kayu untuk Bahan Baku Industri. Balai Riset dan Standardisasi Industri dan Perdagangan, Banjarbaru.

Fachmi. 2014. Analisis Produksi Dan Pendapatan Industri Meubel Di Kota Makassar.Skripsi Pada Jurusan Ilmu Ekonomi, Fakultas Ekonomi Dan Bisnis, Universitas Hasanuddin. Makassar.

Soeka, Y. S., J. Sulistyo., dan D. ENaiola. (2008). Analisis biokimia minyak kelapa hasil ekstraksi secara fermentasi. Jurnal Biodiversitas. 